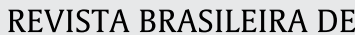

\section{Pupal parasitoids associated with Ceratitis capitata (Wiedemann) (Diptera: Tephritidae) in a semiarid environment in Brazil}

\author{
Bárbara Karine de Albuquerque Silva ${ }^{1}$, Hellanny Matos da Silva ${ }^{1}$, \\ Elania Clementino Fernandes ${ }^{1}$, Valmir Antonio Costa ${ }^{2}$, \\ Elton Lucio Araujo ${ }^{1 *}$ (1)
}

${ }^{1}$ Universidade Federal Rural do Semi-Árido, Departamento de Ciências Agronômicas e Florestais, Mossoró, RN, Brasil. ${ }^{2}$ Centro Avançado de Pesquisa em Proteção Fitossanitária e Saúde Animal, Instituto Biológico, Campinas, SP, Brasil.

\section{A R T I C L E I N F O}

\section{Article history:}

Received 03 October 2019

Accepted 23 March 2020

Available online 15 May 2020

Associate Editor: Diana Grisales Ochoa

\section{Keywords}

Biodiversity

Caatinga biome

Mediterranean fruit fly

Natural enemies

\begin{abstract}
A B S T R A C T
Fruit flies (Diptera: Tephritidae) are important pests that affect the fruit-growing worldwide. In the northeastern Brazil, where a semiarid climate predominates and the production of tropical fruits for export is concentrated, some fruit flies, including Anastrepha spp. and Ceratitis capitata(Wiedemann), are considered pests due to economic damage and quarantine restrictions. In several parts of the world, fruit fly population regulation is carried out with the support of hymenopteran parasitoids. In Brazil, some information exists about larval parasitoids of fruit flies, but little is known about pupal parasitoids of these tephritids, especially in Brazilian semiarid environments. Therefore, the main objective of this study was to know the pupal parasitoids associated with $C$. capitata in a semiarid environment in Brazil. The parasitoid survey was carried out in a semiarid region in the states of Rio do Norte and Ceará. To obtain the parasitoids, pupae (sentinels) of $C$. capitata from the laboratory, Applied Entomology Laboratory of Universidade Federal Rural do Semi-Árido, were exposed to natural parasitism in the field. Six parasitoid (Hymenoptera) species were obtained: Pachycrepoideus vindemmiae (Rondani), Spalangia simplex Perkins, Spalangia gemina Boucek, Spalangia leiopleura Gibson, and Spalangia impunctata Howard (Pteromalidae); Trichopria anastrephae Lima (Diapriidae). These are the first records of pupal parasitoids associated with the fruit fly C. capitata in Brazil.
\end{abstract}

\section{Introduction}

Fruit flies (Diptera: Tephritidae) are considered pests that affect the fruit-growing worldwide (White and Elson-Harris, 1992; Szyniszewska and Tatem, 2014). The fruit flies oviposit inside the fruits and their larvae feed on the pulp, making them unsuitable for fresh consumption and industrialization. After completing their development, the larvae leave the fruits and bury themselves in the soil to pupate, after a few days the adults emerge (White and Elson-Harris, 1992). In Brazil, Ceratitis capitata (Wiedemann) and several species from genus Anastrepha Schiner are important, due to economic damages and quarantine restrictions (Malavasi and Zucchi, 2000; Vilela and Zucchi, 2015). Some Anastrepha species are endemic to Brazil, whereas $C$. capitata was first detected in the country in 1901 (Zucchi, 2000).

In semiarid regions of Brazil, where the Caatinga biome predominates and tropical fruit production is concentrated, $C$. capitata was detected

\footnotetext{
* Corresponding author.

E-mail: elton@ufersa.edu.br (E.L. Araujo).
}

in the early 1990s and is currently considered one of the region's key fruit pests (Araujo et al., 2013). The Caatinga biome is characterized by its vegetation with xerophyte and deciduous plants. The climate is predominantly hot semi-arid (BSh type), with sparse and irregular rainfall (average annual rainfall of $600 \mathrm{~mm}$ ), high average temperatures $\left( \pm 28^{\circ} \mathrm{C}\right)$ and low air humidity $( \pm 65 \%$ ) (Sousa et al., 2019).

For the control of $C$. capitata populations, it is important to know its natural enemies that can be used in integrated management programs, and the parasitoids are among the main natural enemies of this fruit fly (Aluja et al., 2014). However, as most of the life cycle of $C$. capitata occurs protected inside the fruit (egg and larval stage) and buried in the soil (pupal stage), the control of this fruit fly and the survey of its parasitoids, especially pupal parasitoids, is difficult. The methodology currently used for the survey of fruit fly parasitoids, which is based on the collection of fruits, allows only the knowledge of the egg and larval parasitoids, but it is not possible to know the pupal parasitoids. 
In Brazil, fruit fly parasitoid surveys have been practically restricted to larvae parasitoids, and these surveys have indicated that hymenopteran parasitoids (Braconidae and Figitidae) are the most common in several regions of the country and are associated mainly with species of Anastrepha (Garcia and Corseuil, 2004; Souza-Filho et al., 2009; Silva et al., 2010; Souza et al., 2012; Taira et al., 2013).

Little is known about pupal fruit fly parasitoids and this information is concentrated to Brazil's central and southern regions, where some hymenopteran parasitoids, including Pachycrepoideus vindemmiae (Rondani), Spalangia simplex Perkins, Spalangia endius Walker, and Spalangia gemina Bouček (Pteromalidae); Trichopria anastrephae Lima and Coptera haywardi Loiácono (Diapriidae), were found parasitizing pupae of Anastrepha (Marchiori et al., 2000; Aguiar-Menezes et al., 2003; Uchôa-Fernandes et al., 2003; Garcia and Corseuil, 2004; Cruz et al., 2011). There are no records of pupal parasitoids associated with $C$. capitata (Paranhos et al., 2019). In semiarid regions of Brazil, the obtained information is related only to fruit fly larvae parasitoids (Araujo and Zucchi, 2002; Alvarenga et al., 2009; Araujo et al., 2015). However, knowing pupal parasitoids is important because these can be used to regulate the population of $C$. capitata. Therefore, this study's main objective was to know the pupal parasitoids associated with C. capitata, in a semiarid environment in Brazil.

\section{Material and methods}

To collect the parasitoids, live C. capitata (strain Vienna 8) pupae were exposed to parasitism throughout the studied zone using the sentinel pupae technique (Petersen and Watson, 1992). Ceratitis capitata (strain Vienna 8) pupae were obtained from the Applied Entomology Laboratory of Universidade Federal Rural do Semi-Árido (UFERSA) (Mossoró, Rio Grande do Norte, Brazil), as unirradiated 48 hours-old pupae.

The $C$. capitata pupae were exposed to natural field parasitism in transparent plastic containers (parasitism units) with a capacity of $500 \mathrm{ml}$ (12 cm in diameter $x 7 \mathrm{~cm}$ in height) with the upper part open. In each parasitism unit, 200 pupae (48 hours-old) were placed under a thin layer of vermiculite. The parasitism units were distributed in nine different locations of a semiarid region in the states of Rio Grande do Norte (RN) and Ceará (CE), Brazil: Municipality of Mossoró (RN) - Local 1 (5 $5^{\circ} 12^{\prime} 34.3^{\prime \prime S}$

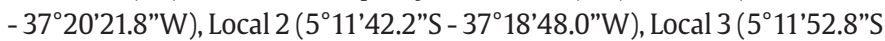
- $\left.37^{\circ} 18^{\prime} 31.3^{\prime \prime} \mathrm{W}\right)$, and Local 4 ( $\left.5^{\circ} 03^{\prime} 44.5^{\prime \prime} \mathrm{S}-37^{\circ} 24^{\prime} 08.5^{\prime \prime W}\right)$; Municipality of Ipanguaçu (RN) - Local 5 (5 32'6.60"S - 36 52'16.06”W); Municipality of Limoeiro do Norte (CE) - Local 6 ( $5^{\circ} 09^{\prime} 44.7^{\prime \prime} \mathrm{S}$; 38 $\left.06^{\circ} 21.6^{\prime \prime} \mathrm{W}\right)$, Local 7

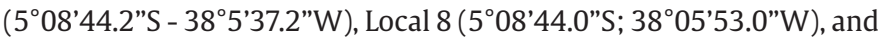
Local 9 ( $\left.5^{\circ} 04^{\prime 2} 27.0^{\prime \prime} \mathrm{S} ; 38^{\circ} 06^{\prime 2} 21.6^{\prime \prime} \mathrm{W}\right)$ (Table 1$)$.

For each studied location, each 15 days one parasitism units was exposed in the field for 48 hours, during the period from May to September 2016. Then, a total of 90 parasitism units were used, with one parasitism unit per location and sampling date. To avoid predation by soil insects, the parasitism units were placed inside plastic trays (51 x $30 \times 9.5 \mathrm{~cm}$ [1 x w x h]) containing a solution of water and detergent (10\%).

After field exposure, the parasitism units were retrieved to the laboratory, and the pupae were placed inside Petri dishes $(10 \mathrm{~cm}$ in diameter $x 1.5 \mathrm{~cm}$ in height) under a thin layer $(4 \mathrm{~cm})$ of moist vermiculite. The Petri dishes were then closed with voile fabric and kept in a climate-controlled room at a temperature of $25 \pm 2^{\circ} \mathrm{C}$, relative humidity of $70 \pm 10 \%$ and a photoperiod of $12: 12 \mathrm{~h}$ (L:D), where they remained until the emergence of adults (flies or parasitoids). Parasitoids that emerged were counted and fixed in $70 \%$ alcohol for later specific identification.

The parasitoids were identified based on Bouček and Heydon (1997), Gibson (2009) and Rueda and Axtell (1985) taxonomical keys. Voucher specimens were deposited in the parasitoid hymenoptera collection at the Biological Institute, Campinas, São Paulo, Brazil.

\section{Results and discussion}

A total of 194 parasitoids (Hymenoptera) belonging to six species and two families were obtained: $P$. vindemmiae ( $\mathrm{n}=142 / 73.2 \%$ ), S. $\operatorname{simplex}(\mathrm{n}=32 / 16.5 \%)$, S. gemina $(\mathrm{n}=13 / 6.7 \%)$, Spalangia leiopleura Gibson ( $\mathrm{n}=5 / 2.6 \%)$ and Spalangia impunctata Howard $(\mathrm{n}=1 / 0.5 \%)$ (Pteromalidae); . anastrephae $(\mathrm{n}=1 / 0.5 \%)$ (Diapriidae) (Table 1$)$.

The considerable diversity of Pteromalidae (Chalcidoidea) collected is possibly related to the fact that the main genera of pupal parasitoids of fruit flies in the world belong to this family (Noyes, 2014). Although most parasitoid species collected in this study had already been registered in Brazil, this is the first report of $S$. impunctata in the country. Among the pupal fruit fly parasitoids reported in Brazil, only S. endius (Aguiar-Menezes et al., 2003; Silva et al., 2003; Uchôa-Fernandes et al., 2003; Nicácio et al., 2011) and C. haywardi (Aguiar-Menezes et al., 2003) were not collected during the present study (Table 2).

Pachycrepoideus vindemmiae was the most common species in this survey, possibly due to its generalist behaviour (Marchiori et al., 2013; Zhao et al., 2013), which favors its presence in various environments and regions. In several parts of the world, records indicate that $P$. vindemmiae parasitizes species of fruit flies of economic importance in the genera Anastrepha, Ceratitis, Bactrocera, and Rhagoletis(Noyes, 2014). In some arid regions such as Tunisia and Benin, $P$. vindemmiae has been recorded parasitizing pupae of $C$. capitata (Harbi et al., 2015) and Bactrocera invadens Drew, Tsuruta \& White (Vayssières et al., 2011).

Pachycrepoideus vindemmiae was introduced in the Americas from West Africa and India (Purcell, 1998) to control Anastrepha species and C. capitata (Ovruski et al., 2000). Due to its wide range of hosts, which includes at least 57 species in 14 dipteran families (Noyes, 2014), this parasitoid has spread to various countries in the Americas, where it is quite common in surveys. In Mexico, for example, $P$. vindemmiae was obtained from Anastrepha striata Schiner and Anastepha ludens (Loew) (Sánchez-García et al., 2014). For Ceratitis, there are reports of this parasitoid associated with $C$. cosyra Walker, $C$. silvestrii Bezzi, C. quinaria Bezzi, $C$. fasciventris Bezzi, $C$. anonae Graham, $C$. ditissima Munro, and C. capitata in Africa (Vayssières et al., 2002). In Argentina, $P$. vindemmiae was obtained from $C$. capitata (Ovruski et al., 2006). In Brazil, $P$. vindemmiae has been reported parasitizing Anastrepha species in the central-western and southern regions of the country, in

Table 1.

Pupal parasitoids recorded in association with the fruit fly Ceratitis capitata in the States of Rio Grande do Norte (RN) and Ceará (CE), Brazilian semiarid.

\begin{tabular}{|c|c|}
\hline $\begin{array}{c}\text { Municipalities/States } \\
\text { Local - Geographical coordinates }\end{array}$ & $\begin{array}{c}\text { Parasitoid species } \\
\text { (Number of parasitoids collected) }\end{array}$ \\
\hline \multicolumn{2}{|l|}{ Mossoró/RN } \\
\hline Local 1: 5¹2'34.3"S; 37²0’21.8"W & $\begin{array}{l}\text { Pachycrepoideus vindemmiae(106); } \\
\text { Spalangia leiopleura (3) }\end{array}$ \\
\hline Local 2: $5^{\circ} 11^{\prime} 42.2^{\prime \prime} \mathrm{S} ; 37^{\circ} 18^{\prime} 48.0^{\prime \prime} \mathrm{W}$ & $\begin{array}{l}\text { P. vindemmiae (4); Spalangia simplex (4); } \\
\text { S. leiopleura (2) }\end{array}$ \\
\hline Local 3: 5¹1’52.8”S; 37¹8’31.3”W & S. simplex (8); Spalangia impunctata(1) \\
\hline $\begin{array}{l}\text { Local } 4: 5^{\circ} 03^{\prime} 44.5^{\prime \prime} \mathrm{S} ; 37^{\circ} 24^{\prime} 08.5^{\prime \prime} \mathrm{W} \\
\text { Ipanguaçu/RN }\end{array}$ & P. vindemmiae (3) \\
\hline Local 5: 5³2'6.60"S; 3652'16.1"W & P. vindemmiae (6) \\
\hline \multicolumn{2}{|l|}{ Limoeiro do Norte/CE } \\
\hline Local 6: 509'44.7”S; 3806'21.6”W & Spalangia gemina (13) \\
\hline Local 7: 508’44.2”S; $38^{\circ} 05^{\prime} 37.2^{\prime \prime} \mathrm{W}$ & P. vindemmiae (23) \\
\hline Local 8: $5^{\circ} 08^{\prime} 44.0^{\prime \prime} \mathrm{S} ; 38^{\circ} 05^{\prime} 53.0^{\prime \prime} \mathrm{W}$ & S. simplex (20) \\
\hline Local 9: 504'27.0”S; 3806’21.6”W & Trichopria anastrephae(1) \\
\hline
\end{tabular}


Table 2.

Pupal parasitoids recorded in association with fruit flies (Anastrepha spp. and Ceratitis capitata) in Brazil.

\begin{tabular}{|c|c|c|c|}
\hline Parasitoid species & Municipalities/States & Hosts (Tephritidae) & References \\
\hline \multicolumn{4}{|l|}{ Pteromalidae } \\
\hline \multirow[t]{8}{*}{ Pachycrepoideus vindemmiae } & Mossoró/RN** & Ceratitis capitata*** & \\
\hline & Ipanguaçu/RN** & C. capitata*** & \\
\hline & Limoeiro do Norte/CE ${ }^{* *}$ & C. capitata*** & \\
\hline & Itumbiária/GO & Anastrepha fraterculus & Marchiori et al. (2000) \\
\hline & Presidente Prudente/SP & Anastrepha spp. and/or C. capitata & Montes et al. (2011) \\
\hline & Seropédica/RJ & A. fraterculus and/or $A$. sororcula & Aguiar-Menezes et al. (2003) \\
\hline & Pelotas/RS & A. fraterculus & Salles (1996) \\
\hline & Divinópolis/MG & Anastrepha spp. & Silva et al. (2003) \\
\hline \multirow[t]{4}{*}{ Spalangia endius } & Not mentioned/MS & Anastrepha spp. and/or A. obliqua & Uchôa-Fernandes et al. (2003) \\
\hline & Seropédica/RJ & A. fraterculus and/or A. sororcula & Aguiar-Menezes et al. (2003) \\
\hline & Passo do Lontra/MS & A. alveatoides & Nicácio et al. (2011) \\
\hline & Divinópolis/MG & Anastrepha spp. & Silva et al. (2003) \\
\hline \multirow[t]{3}{*}{ Spalangia gemina } & Limoeiro do Norte/CE ${ }^{* *}$ & C. capitata*** $^{* *}$ & \\
\hline & Not mentioned/MS & Anastrepha spp. and $A$. obliqua & Uchôa-Fernandes et al. (2003) \\
\hline & Seropédica/RJ & A. fraterculus and/or $A$. sororcula & Aguiar-Menezes et al. (2003) \\
\hline \multirow[t]{3}{*}{ Spalangia simplex } & Mossoró/RN** & C. capitata*** & \\
\hline & Limoeiro do Norte/CE ${ }^{* *}$ & C. capitata*** & \\
\hline & Jaboticabal/SP & A. serpentina & Fernandes et al. (2013) \\
\hline Spalangia leiopleura & Mossoró/RN** & C. capitata*** & \\
\hline Spalangia impunctata* & Mossoró/RN** & C. capitata $^{* * *}$ & \\
\hline \multicolumn{4}{|l|}{ Diapriidae } \\
\hline Coptera haywardi & Seropédica/RJ & A. fraterculus and/or $A$. sororcula & Aguiar-Menezes et al. (2003) \\
\hline \multirow[t]{7}{*}{ Trichopria anastrephae } & Limoeiro do Norte/CE** & C. capitata $^{* * *}$ & \\
\hline & Capão do Leão/RS & A. fraterculus & Cruz et al. (2011) \\
\hline & Not mentioned/SC & A. fraterculus & Garcia and Corseuil, 2004 \\
\hline & Seropédica/RJ & A. fraterculus & Aguiar-Menezes et al., 2001 \\
\hline & Una/BA & Anastrepha spp. & Souza-Filho et al. (2007) \\
\hline & Divinópolis/MG & Anastrepha spp. & Silva et al. (2003) \\
\hline & Not mentioned/RJ & Anastrepha sp. and $A$. serpentina & Lima (1940) \\
\hline
\end{tabular}

${ }^{*}$ First reports in Brazil; ${ }^{* *}$ New distribution reports; ${ }^{* * *}$ New reports of association with fruit flies in Brazil.

the states of Rio Grande do Sul (Salles, 1996), Goiás (Marchiori et al., 2000), Rio de Janeiro (Aguiar-Menezes et al., 2003) and Minas Gerais (Silva et al., 2003). Pachycrepoideus vindemmiae was also reported to parasitize fruit flies in São Paulo (Montes et al., 2011). However, it was unclear whether the parasitoids were obtained from Anastrepha species or $C$. capitata. In the present study, $P$. vindemmiae was recorded for the first time parasitizing pupae of $C$. capitata (Table 2 ) in a semiarid region of Brazil, states of Rio Grande do Norte and Ceará (Fig. 1).

The diversity of Spalangia species ( $S$. simplex, S. gemina, S. leiopleura, and $S$. impunctata) in this survey shows that these parasitoids can be common in semiarid environment. Spalangia species are typically generalists and parasitize pupae of various dipteran families, such as Muscidae, Calliphoridae, Sarcophagidae, Drosophilidae, and Tephritidae (Gibson, 2009; Beitia et al., 2016). In Brazil, there are records of Spalangia parasitizing fruit flies only in the southeastern and center-west regions (Aguiar-Menezes et al., 2003; Silva et al., 2003; Uchôa-Fernandes et al., 2003; Nicácio et al., 2011; Fernandes et al., 2013). Therefore, these are the first reports of Spalangia species associated with pupae of fruit flies (C. capitata) in a semiarid region of Brazil (Fig. 1).

In Africa, there are reports of $S$. simplex parasitizing pupae of various Ceratitis species (Vayssières et al., 2002). In the Americas, S. simplex has been observed to parasitize Anastrepha species, such as $A$. ludens in Mexico, Anastrepha suspensa (Loew) in the United States and Anastrepha acidusa (Walker) in Puerto Rico (Gibson, 2009). In Brazil, S. simplex was only obtained from pupae of Anastrepha serpentina (Wiedemann) in the state of São Paulo (Fernandes et al., 2013). Thus, this is the first record of S. simplex in association with pupae of $C$. capitata in Brazil (Table 2).
Spalangia gemina was described based on specimens collected in India, Thailand, Malaysia, Fiji, Mauritius, and Venezuela, indicating the species' widespread distribution worldwide (Bouček, 1963). In Asia and Africa, there are records of $S$. gemina parasitizing Bactrocera dorsalis (Hendel) and B. cucurbitae (Coquillett) (Bouček, 1963; Vayssières et al., 2001). In Brazil, S. gemina was obtained from Anastrepha species in the states of Mato Grosso do Sul (Uchôa-Fernandes et al., 2003) and Rio de Janeiro (Aguiar-Menezes et al., 2003). Therefore, this is the first report of $S$. gemina parasitizing $C$. capitata pupae in Brazil (Table 2).

The species $S$. leiopleura was described based on specimens collected in North America and Mexico (Gibson, 2009). Recently this species was reported in Brazil in the state of Minas Gerais. However, this report was based on specimens collected in traps, so it was not possible to know its host (Juliato et al., 2017). In this study, S. leiopleura was collected from $C$. capitata pupae in Rio Grande Norte, so this is the first record of the association of $S$. leiopleura with a host of the Tephritidae family in Brazil.

Spalangia impunctata is possibly a circumtropical species (Gibson, 2009). This species was described based on specimens obtained from Drosophila Fallén pupae in India (Sureshan and Farsana, 2014). As reported, this is the first record of $S$. impunctata in Brazil. The specimens of $S$. impunctata were obtained from pupae of $C$. capitata in Rio Grande do Norte. This shows that Brazilian semiarid regions may contain species not yet reported in Brazil.

Trichopria anastrephae was described based on specimens obtained from pupae of Anastrepha sp. and A. serpentina in Rio de Janeiro, Brazil (Lima, 1940). Of the 12 Trichopria species cataloged in Brazil, T. anastrephae was the only one reported to parasitize Anastrepha 
Coptera haywardi 凶Spalangia endius

$\triangle$ Spalangia impunctata

- Spalangia leiopleura

※ Spalangia simplex

- Spalangia gemina

$\because$ Pachycrepoideus vindemmiae

* Trichopria anastrephae

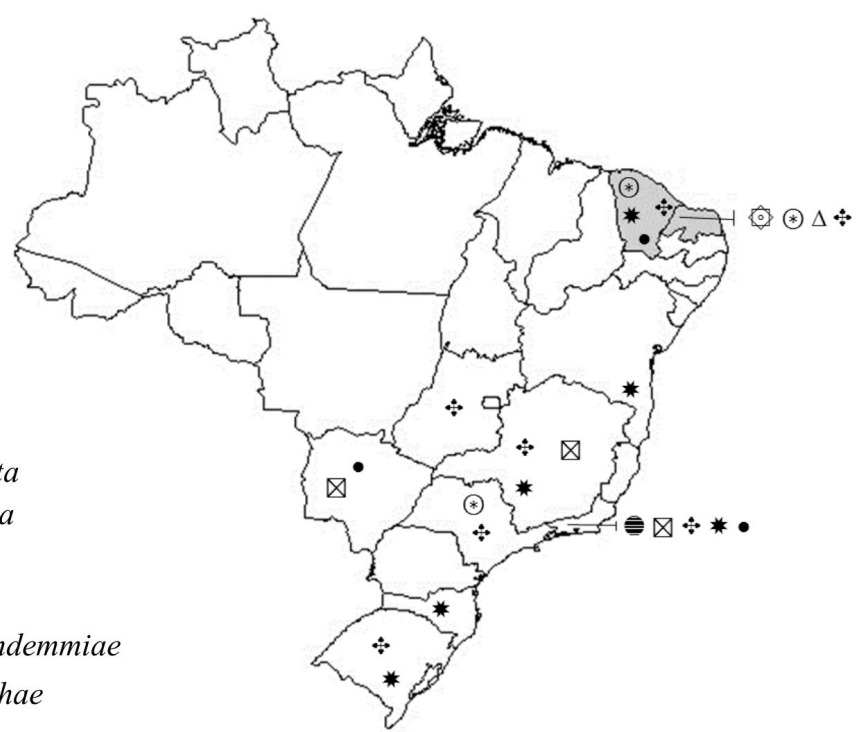

States with new reports of pupal parasitoids associated with fruit flies (Ceratitis capitata) in Brazilian semiarid.

Figure 1 States with recordings of pupal parasitoids associated with fruit flies (Anastrepha spp. and / or Ceratitis capitata) in Brazil.

(Santis, 1980; Margaria, 2019). Trichopria anastrephae has been observed parasitizing fruit flies (Anastrepha) in the states of Rio de Janeiro (Lima, 1940; Aguiar-Menezes et al., 2001), Minas Gerais (Silva et al., 2003), Rio Grande do Sul (Garcia and Corseuil, 2004; Cruz et al., 2011) and Bahia (Souza-Filho et al., 2007). Therefore, this is the first record of T. anastrephae in a semiarid environment, and it is also the first time that $T$. anastrephae has been observed parasitizing $C$. capitata pupae in Brazil (Table 2).

In Brazil, the few reports of fruit fly pupae parasitoids known are concentrated in the midwestern and southern regions, which indicate that surveys of these parasitoids have been neglected in various regions of the country. In this study, six species of parasitoids are recorded for the first time, obtained from pupae (sentinels) of $C$. capitata distributed in a semiarid environment in northeastern Brazil. This information extends reports of pupae parasitoids associated with fruit flies in Brazil and records the presence of $S$. impunctata in the country for the first time. In addition, reports were made from pupae of $C$. capitata, which is an important exotic species that is spreading in Brazilian semiarid regions.

Therefore, the information obtained shows that if surveys are expanded, new reports of parasitoids associated with fruit fly pupae may be recorded in various regions of the country. Thus, further studies on these pupal parasitoids should be performed, aiming at their use in the management of $C$. capitata in fruit orchards located in semiarid regions of Brazil.

\section{Acknowledgments}

We wish to thank the National Council for Scientific and Technological Development (CNPq) for the scholarships granted to authors Bárbara K. A. Silva (Master), Elton L. Araujo (Productivity in Research / Process $\left.\mathrm{N}^{\circ} 307750 / 2012-4\right)$ for their financial support to Valmir A. Costa (Productivity in Research). We also wish to thank the National Institute of Science and Technology of the Hymenoptera Parasitoids of the Southeast Brazilian Region (INCT - Hympar Sudeste) for their financial support of Valmir A. Costa.

\section{Conflicts of interest}

The authors declare no conflicts of interest.

\section{Compliance with ethical standards}

This study was carried out following ethical standards.

\section{Author contribution statement}

BKA Silva, HM Silva and EC Fernandes carried out sampling of the parasitoids. VA Costa identified the parasitoids and reviewed the article. EL Araujo coordinated the study and wrote the final version of the article.

\section{References}

Aguiar-Menezes, E. L., Menezes, E. B., Loiácono, M. S., 2003. First record of Coptera haywardi Loiácono (Hymenoptera: Diapriidae) as a parasitoid of fruit-infesting Tephritidae (Diptera) in Brazil. Neotrop. Entomol. 32 (2), 355-358. http://dx.doi.org/10.1590/ S1519-566X2003000200025.

Aguiar-Menezes, E. L., Menezes, E. B., Silva, P. S., Bittar, A. C., Cassino, P. C. R., Silva, P. S., 2001. Native hymenopteran parasitoids associated with Anastrepha spp. (Diptera: Tephritidae) in Seropedica City, Rio De Janeiro, Brazil. Fla. Entomol. 84 (4), 706-711. http://dx.doi. org/10.2307/3496405.

Aluja, M., Sivinski, J., Van Driesche, R., Anzures-Dadda, A., Guillén, L., 2014. Pest management through tropical tree conservation. Biodivers. Conserv. 23 (4), 831-853. http://dx.doi.org/10.1007/ s10531-014-0636-3.

Alvarenga, C. D., Matrangolo, C. A. R., Lopes, G. N., Silva, M. A., Lopes, E. N., Alves, D. A., do Nascimento, A. S., Zucchi, R. A., 2009. Moscasdas-frutas (Diptera: Tephritidae) e seus parasitóides em plantas hospedeiras de três municípios do norte de Minas Gerais. Arq. Inst. Biol. 76, 195-204. 
Araujo, E. L., Fernandes, E. C., Silva, R. I. R., Ferreira, A. D. C. L., Costa, V. A., 2015. Parastioides (Hymenoptera) de moscas-das-frutas (Diptera: Tephritidae) no Semiárido do estado do Ceará, Brasil. Rev. Bras. Frutic. 37 (3), 610-616. http://dx.doi.org/10.1590/0100-2945-188/14.

Araujo, E. L., Ribeiro, J. C., Chagas, M. C. M., Dutra, V. S., Silva, J. G., 2013. Moscas-das-frutas (Diptera: Tephritidae) em um pomar de goiabeira, no semiárido Brasileiro. Rev. Bras. Frutic. 35 (2), 471-476. http:// dx.doi.org/10.1590/S0100-29452013000200016.

Araujo, E. L., Zucchi, R. A., 2002. Parasitóides (Hymenoptera: Braconidae) de moscas-das-frutas (Diptera: Tephritidae) na Região de Mossoró/ Assú, Estado do Rio Grande do Norte. Arq. Inst. Biol. 69, 65-68.

Beitia, F., Valencia, E., Peris, B., Pedro, L., Asís, J. D., Tormos, J., 2016. Influence of natal host on parasitism by Spalangia cameroni (Hymenoptera: pteromalidae). Eur. J. Entomol. 113, 99-103. http:// dx.doi.org/10.14411/eje.2016.012.

Bouček, Z., 1963. A taxonomic study in Spalangia Latr. (Hymenoptera, Chalcidoidea). Acta Entomol. Mus. Natl. Pragae 35, 429-512.

Bouček, Z., Heydon, S. L., 1997. Pteromalidae. In: Gibson, G.A.P., Huber, J.T., Woolley, J.B. (Eds.), Annotated Keys to the Genera of Nearctic Chalcidoidea (Hymenoptera). NRC Research, Ottawa, pp. 541-692. Available in: http://www.nrcresearchpress.com/doi/ abs/10.1139/9780660166698\#.VrqjAhgrKUk (accessed 3 October 2019).

Cruz, P. P., Neutzling, A. S., Garcia, F. R. M., 2011. Primeiro registro de Trichopria anastrephae, parasitoide de moscas-das-frutas no Rio Grande do Sul. Cienc. Rural 41 (8), 1297-1299. http://dx.doi. org/10.1590/S0103-84782011000800001.

Fernandes, D. R. R., Vacari, A. M., Araujo, E. L., Guimarães, J. A., Bortoli, S. A. D., Perioto, N. W., 2013. Frugivorous flies (Diptera: Tephritidae and Lonchaeidae) and native parasitoids (Hymenoptera) associated with Pouteria caimito (Sapotaceae) in Brazil. Fla. Entomol. 96 (1), 255-257. http://dx.doi.org/10.1653/024.096.0139.

Garcia, F. R. M., Corseuil, E., 2004. Native hymenopteran parasitoids associated with fruit flies (Diptera: Tephritidae) in Santa Catarina state, Brazil. Fla. Entomol. 87 (4), 517-521. http://dx.doi.org/10.1653/00154040(2004)087[0517:NHPAWF]2.0.CO;2.

Gibson, G. A. P., 2009. Revision of new world Spalangiinae (Hymenoptera: Pteromalidae).Zootaxa 2259 (1), 1-159. http://dx.doi.org/10.11646/ zootaxa.2259.1.1.

Harbi, A., Beitia, F., Sabater-Muñoz, B., Falcó, J. V., Chermiti, B., 2015. First record of Pachycrepoideus vindemmiae(Rondani) (Hymenoptera: Pteromalidae) parasitizing pupae of Ceratitis capitata(Wiedemann) (Diptera: Tephritidae) in Tunisia. Afr. Entomol. 23 (2), 514-518. http://dx.doi.org/10.4001/003.023.0212.

Juliato, B. S., Siqueira, M. A., Costa, V. A., 2017. Spalangia leiopleura Gibson, 2009 (Hymenoptera: Pteromalidae): First record from Brazil. Check List 13 (4), 71-74. http://dx.doi.org/10.15560/13.4.71.

Lima, A. C., 1940. Alguns parasitos de moscas de frutas. An. Acad. Bras. Cienc. 12, 17-20.

Malavasi, A., Zucchi, R. A., 2000. Biogeografia. In: Malavasi, A., Zucchi, R.A. (Eds.), Moscas-das-frutas de importância econômica no Brasil: conhecimento básico e aplicado. Holos, Ribeirão Preto, pp. 93-98.

Marchiori, C. H., Borges, L. M. F., Ferreira, L. L., 2013. Hosts of the parasitoid Pachycrepoideus vindemmiae(Rondani) (Hymenoptera: Pteromalidae) of medical-veterinary and economic importance collected in the State of Goiás, Brazil. Am. J. Life Sci. 1 (5), 228-231. http://dx.doi.org/10.11648/j.ajls.20130105.14.

Marchiori, C. H., Oliveira, A. M. S., Martins, F. F., Bossi, F. S., Oliveira, A. T., 2000. Espécies de moscas-da-fruta (Diptera: Tephritidae) e seus parasitóides em Itumbiara-GO. Pesqui. Agropecu. Trop. 30, 73-76.

Margaria, C., 2019. Catálogo taxonômico da fauna do Brasil. Jardim Botânico do Rio de Janeiro, Rio de Janeiro. Available in: fauna.jbrj.
gov.br/fauna/listaBrasil/PrincipalUC/PrincipalUC.do?lingua=pt\%0D (accessed 3 October 2019).

Montes, S. M. N. M., Raga, A., Boliani, A. C., Santos, P. C., 2011. Dinâmica populacional e incidência de moscas-das-frutas e parasitoides em cultivares de pessegueiros (Prunus persica L. Batsch) no município de Presidente Prudente-SP. Rev. Bras. Frutic. 33 (2), 402-411. http:// dx.doi.org/10.1590/S0100-29452011005000052.

Nicácio, J. N., Uchôa, M. A., Faccenda, O., Guimarães, J. A., Marinho, C. F., 2011. Native larval parasitoids (Hymenoptera) of frugivorous tephritoidea (Diptera) in south pantanal region, Brazil. Fla. Entomol. 94 (3), 407-419. http://dx.doi.org/10.1653/024.094.0305.

Noyes, J. S., 2014. Universal Chalcidoidea Database. Available in: http:// www.nhm.ac.uk/chalcidoids (accessed 3 October 2019).

Ovruski, S., Aluja, M., Sivinski, J., Wharton, R., 2000. Hymenopteran parasitoids on fruit-infesting Tephritidae (Diptera) in Latin America and the southern United States: Diversity, distribution, taxonomic status and their use in fruit fly biological control. Integr. Pest Manage. Rev. 5 (2), 81-107. http://dx.doi.org/10.1023/A:1009652431251.

Ovruski, S. M., Oroño, L., Nuñez-Campero, S. R., Schiliserman, P., AlbornozMedina, P., Bezdjian, L. P., Van Nieuwenhove, G. A., Martin, C. B., 2006. A review of hymenopterous parasitoid guilds attacking Anastrepha spp. and Ceratitis capitata (Diptera: Tephritidae) in Argentina. In: 7th International Symposium on Fruit Flies of Economic Importance, 2006, Salvador. Proceedings. São Paulo: SBPC, pp. 113-125.

Paranhos, B. J., Nava, D. E., Malavasi, A., 2019. Biological control of fruit flies in Brazil. Pesqui. Agropecu. Bras. 54, e26037. http://dx.doi. org/10.1590/s1678-3921.pab2019.v54.26037.

Petersen, J.J., Watson, D. W., 1992. Comparison of sentinel and naturally occurring fly pupae to measure field parasitism by pteromalid parasitoids (Hymenoptera). Biol. Control 2 (3), 244-248. http:// dx.doi.org/10.1016/1049-9644(92)90065-L.

Purcell, M. F., 1998. Contribution of biological control to integrated pest management of Tephritidae fruit flies in the tropics and subtropics. Int. J. Pest Manage. 3, 63-83.

Rueda, L. M., Axtell, R. C., 1985. Guide to Common Species of Pupal Parasites (Hymenoptera, Pteromalidae) of the House Fly and Other Muscoid Flies Associated with Poultry and Livestock Manure. North Carolina Agricultural Research Service, Raleigh. (Technical Bulletin, 278).

Salles, L. A. B., 1996. Parasitismo de Anastrepha fraterculus (Wied.) (Diptera: Tephritidae) por Hymenoptera, na região de Pelotas, RS. Pesqui. Agropecu. Bras. 31, 769-774.

Sánchez-García, J. A., Avendaño-Flores, S., Martínez-Martinez, L., Figueroa-de la Rosa, J. I., Jarquín-López, R., 2014. Parasitoides asociados a moscas de la fruta del género Anastrepha Schiner (Diptera: Tephritidae) en Oaxaca, México. Nat. Desarro. 12, 46-58.

Santis, D. L., 1980. Catalogo de los Himenopteros Brasileños de la Serie Parasitica incluyendo Bethyloidea. Editora da Universidade Federal do Paraná, Curitiba.

Silva, C. G., Marchiori, C. H., Fonseca, A. R., Torres, L. C., 2003. Himenópteros parasitoides de larvas de Anastrepha spp. em frutos de carambola (Averrhoa caramboa L.) na região de Divinópolis, Minas Gerais, Brasil. Cienc. Agrotec. 27 (6), 1264-1267. http://dx.doi.org/10.1590/ S1413-70542003000600009.

Silva, J. G., Dutra, V. S., Santos, M. S., Silva, N. M. O., Vidal, D. B., Nink, R. A., Guimarães, J. A., Araujo, E. L., 2010. Diversity of Anastrepha spp. (Diptera: Tephritidae) and associated Braconid parasitoids from native and exotic hosts in southeastern Bahia, Brazil. Environ. Entomol. 39 (5), 1457-1465. PMid:22546440. http://dx.doi.org/10.1603/EN10079. Sousa, M. M., Araujo, E. L., Silva, J. G., Barbosa, D. R. S., Fernandes, E. C., 2019. Fruit flies (Diptera: Tephritidae) in commercial mango 
orchards in a semiarid region of Brazil. Rev. Bras. Frutic. 41 (5), 1-9. http://dx.doi.org/10.1590/0100-29452019347.

Souza, A. R., Lopes-Mielezrski, G. N., Lopes, E. N., Querino, R. B., Corsato, C. D. A., Giustolin, T. A., Zucchi, R. A., 2012. Hymenopteran parasitoids associated with frugivorous larvae in a Brazilian Caatinga-Cerrado ecotone. Environ. Entomol. 41 (2), 233-237. PMid:22506994. http:// dx.doi.org/10.1603/EN11121.

Souza-Filho, M. F. S., Raga, A., Azevedo-Filho, J. A., Strikis, P. C., Guimarães, J. A., Zucchi, R., 2009. Diversity and seasonality of fruit flies (Diptera: Tephritidae and Lonchaeidae) and their parasitoids (Hymenoptera: Braconidae and Figitidae) in orchards of guava, loquat and peach. Braz.J. Biol. 69 (1), 31-40. PMid:19347143. http://dx.doi.org/10.1590/ S1519-69842009000100004.

Souza-Filho, Z. A., Araujo, E. L., Guimarães, J. A., Silva, J. G., 2007. Endemic parasitoids associated with Anastrepha spp. (Diptera: Tephritidae) infesting guava (Psidium Guajava) in southern Bahia, Brazil. Fla. Entomol. 90 (4), 783-785. http://dx.doi.org/10.1653/00154040(2007)90[783:EPAWAS]2.0.CO;2.

Sureshan, P. M., Farsana, V. K. R., 2014. Two new distributional and host records for Spalangia Latreille parasitizing Drosophila sp. on putrefied tender jack fruit (Artocarpus heterophyllus) from Kerala, India. J. Biol. Control 28, 57-61.

Szyniszewska, A. M., Tatem, A. J., 2014. Global assessment of seasonal potential distribution of mediterranean fruit fly, Ceratitis capitata (Diptera: tephritidae). PLoS One 9 (11), e111582. PMid:25375649. http://dx.doi.org/10.1371/journal.pone.0111582.

Taira, T. L., Abot, A. R., Nicácio, J., Uchôa, M. A., Rodrigues, S. R., Guimarães, J. A., 2013. Fruit flies (Diptera, Tephritidae) and their parasitoids on cultivated and wild hosts in the Cerrado-Pantanal ecotone in Mato Grosso do Sul, Brazil. Rev. Bras. Entomol. 57 (3), 300-308. http:// dx.doi.org/10.1590/S0085-56262013000300007.
Uchôa-Fernandes, M. A., Molina, R. M. S., Oliveira, I., Zucchi, R. A., Canal, N. A., Díaz, N. B., 2003. Larval endoparasitoids (Hymenoptera) of frugivorous flies (Diptera, Tephritoidea) reared from fruits of the cerrado of the state of Mato Grosso do Sul, Brazil. Rev. Bras. Entomol. 47 (2), 181-186. http://dx.doi.org/10.1590/S0085-56262003000200005.

Vayssières, J., Wharton, R., Delvare, G., Sanogo, F., 2002. Diversity and pest control potential of hymenopteran parasitoids of Ceratitis spp. on mangos in Mali. In: 6th International Fruit Fly Symposium, 2002, Stellenbosch, South Africa. Proceedings. Irene, South Africa: Isteg Scientific Publications, pp. 461-464.

Vayssières, J. F., Delvare, G., Maldès, J. M., Aberlenc, H. P., 2001. Inventaire preliminaire des arthropodes ravageurs et auxiliaires des cultures maraicheres sur l'ile de la réunion. Int. J. Trop. Insect Sci. 21 (1), 1-22. http://dx.doi.org/10.1017/S1742758400020002.

Vayssières, J. F., Wharton, R., Adandonon, A., Sinzogan, A., 2011. Preliminary inventory of parasitoids associated with fruit flies in mangoes, guavas, cashew pepper and wild fruit crops in Benin. BioControl 56 (1), 35-43. http://dx.doi.org/10.1007/s10526-010-9313-y.

Vilela, E. F., Zucchi, R. A., 2015. Pragas introduzidas no Brasil: insetos e ácaros. FEALQ Piracicaba

White, I. M., Elson-Harris, M. M., 1992. Fruit Flies of Economic Significance: Their Identification and Bionomics. CAB International, Oxon, UK.

Zhao, H.-Y., Zeng, L., Xu, Y.-J., Lu, Y.-Y., Liang, G.-W., 2013. Effects of host age on the parasitism of Pachycrepoideus vindemmiae (Hymenoptera: Pteromalidae), an ectoparasitic pupal parasitoid of Bactrocera cucurbitae (Diptera: Tephritidae). Fla. Entomol. 96 (2), 451-457. http://dx.doi.org/10.1653/024.096.0209.

Zucchi, R. A. 2000. Taxonomia. In: Malavasi, A., Zucchi, R.A. (Eds.), Moscas-das-frutas de importância econômica no Brasil: conhecimento básico e aplicado. Holos, Ribeirão Preto, p. 327. 